\title{
Distribution and Movements of Moose (Alces alces) in Relation to the Trans-Alaska Oil Pipeline ${ }^{1}$
}

\author{
LENNART G. SOPUCK ${ }^{2}$ and DONALD J. VERNAM ${ }^{3}$
}

\author{
(Received 28 January 1985; accepted in revised form 25 July 1985)
}

\begin{abstract}
During late winter 1982 and 1983, the distribution and movements of moose adjacent to the Trans-Alaska Pipeline near Big Delta, Alaska, were examined. Within a $15 \mathrm{~km}$ wide corridor centered on the pipeline, moose distribution was independent of the distance from the pipeline. Of 175 moose trails examined, most $(94 \%)$ crossed the pipeline successfully upon entering the right-of-way regardless of pipe mode or pipe height above ground. Pipe heights above $1.5 \mathrm{~m}$ were adequate for moose passage, but greater heights up to $2.7 \mathrm{~m}$ were preferred. Sections of pipe that were buried or that were specially elevated to facilitate moose passage did not receive preferential use. Moose moved in a meandering fashion whether they were crossing the pipeline or moving within habitats in distant areas. The results of this study supported the hypothesis that the distribution and local movements of moose were not significantly affected by the pipeline.
\end{abstract}

Key words: moose (Alces alces), movements, pipeline, crossing success, habitat use, effects of development

\begin{abstract}
RÉSUMÉ. Au cours des derniers mois des hivers de 1982 et 1983, la distribution et les déplacements d'orignaux le long du pipeline Trans-Alaska près de Big Delta, en Alaska, furent examinés. Dans un corridor d'une largeur de $15 \mathrm{~km}$ centré sur le pipeline, la distribution d'orignaux était indépendante de leur distance du pipeline. Des 175 pistes d'orignal examinées, la plupart (94\%) traversèrent le pipeline sans problèmes indiféremment du type de conduit ou de la hauteur de la canalisation par rapport au sol. Une hauteur de plus de $1.5 \mathrm{~m}$ permettait de façon adéquate le passage d'orignaux, mais les sections d'une hauteur de plus de $2.7 \mathrm{~m}$ étaient préférées. Les sections enterrées ou spécialement élevées en vue de permettre le passage d'orignaux ne recurent aucun usage préférentiel. Les orignaux se deplaçaient de façon sinueuse autant dans leurs traverses du pipeline que dans leurs mouvements dans des habitats lointains. Les résultats de cette étude appuient l'hypothèse selon laquelle la distribution et les déplacements locaux des orignaux ne sont pas afféctes de façon importante par le pipeline.
\end{abstract}

Mots clés: orignal (Alces alces), déplacements, pipeline, succès de traverse, utilisation de l'habitat, effets du développement

Traduit pour le journal par Maurice Guibord.

\section{INTRODUCTION}

A major issue concerning pipeline developments in northern environments is that they would adversely affect ungulate populations. Biologists predicted that the Trans-Alaska Oil Pipeline would affect moose and other large mammals by disrupting their movements, displacing them from adjacent habitats and increasing the demands on their energy reserves as a result of disturbance or delayed movement (Weeden and Klein, 1971; Klein, 1972; Van Ballenberghe, 1978). However, quantitative data on the effects of pipelines on moose are limited, and impact predictions have not been verified to date.

The Trans-Alaska Pipeline was constructed from 1975 to 1977 and extends $1300 \mathrm{~km}$ from Prudhoe Bay to Valdez, Alaska. The $122 \mathrm{~cm}$ diameter pipe is elevated from $1-5 \mathrm{~m}$ above ground for $53 \%$ of its length and is completely buried for the remainder. During planning and construction of the pipeline, efforts were made to facilitate ungulate crossing of the pipeline corridor. For example, special areas of elevated pipeline, providing additional pipe-to-ground clearance, were incorporated into the design.

This study was designed to test the hypothesis that use of adjacent habitat by moose and crossing of the pipeline right-ofway were independent of the presence of the Trans-Alaska Pipeline. The hypothesis was tested by: (1) comparing the distribution, habitat use and movements of moose in the vicinity of the pipeline with those of moose observed in areas distant from the pipeline; (2) comparing the influence of man-made and natural features on the selection of pipeline crossing areas by moose; and (3) determining the effect of the pipeline on the local movements of moose by examining trail patterns in the vicinity of the right-of-way.

\section{STUDY AREA}

The study area, $1000 \mathrm{~km}^{2}$, consisted of a $15 \mathrm{~km}$ wide corridor centered on the Trans-Alaska Pipeline between Pump Station 8 and Big Delta, Alaska, about 55-120 km southeast of Fairbanks (Fig. 1). The area included $65 \mathrm{~km}$ of the pipeline, $86 \%$ of which was above ground and $14 \%$ buried.

The climate of the study area is continental (USDI, 1972). At Big Delta ( $300 \mathrm{~m}$ above sea level) temperatures range from $-54^{\circ} \mathrm{C}$ to $35^{\circ} \mathrm{C}$, and annual precipitation averages $27 \mathrm{~cm}$. Snowfall at this location averages $110 \mathrm{~cm}$ annually and snow on the ground reaches its mean maximum of $27 \mathrm{~cm}$ in February (NOAA, 1983).

Vegetation in the study area includes a variety of communities ranging from white spruce forest (Picea glauca) and deciduous species (Betula papyrifera, Populus tremuloides) on welldrained slopes to lowlands dominated by black spruce $(P$. mariana) and tamarack (Larix laricina). Shrub communities (Salix spp., Alnus crispa, Betula nana and B. glandulosa) occur in riparian areas, which are numerous in the study area, and on burned or disturbed sites.

Elevated sections of the pipeline rest on steel supports, on average $2.5 \mathrm{~m}$ off the ground. A right-of-way about $30 \mathrm{~m}$ wide was cleared and a gravel pad established to enable access by maintenance and security vehicles. The right-of-way and sites where gravel was obtained were seeded with a mixture of exotic grass species. At 70 sites within the study area, the pipeline was specially elevated to heights greater than $3 \mathrm{~m}$ above ground over an average distance of $30 \mathrm{~m}$ to encourage passage by big game animals.

Human activities along the pipeline were limited to occasional visits for maintenance and daily surveillance of the

\footnotetext{
${ }^{1}$ Study funded by the Alyeska Pipeline Service Co. Ltd., Anchorage, Alaska

${ }^{2}$ Renewable Resources Consulting Services Ltd., \#108 - 9865 West Saanich Road, Sidney, British Columbia, Canada V8L 3S1

${ }^{3}$ Renewable Resources, Inc., 1503 West 33rd Avenue, Anchorage, Alaska 99503; present address: Box 81937, College, Alaska 99708, U.S.A.

CThe Arctic Institute of North America
} 


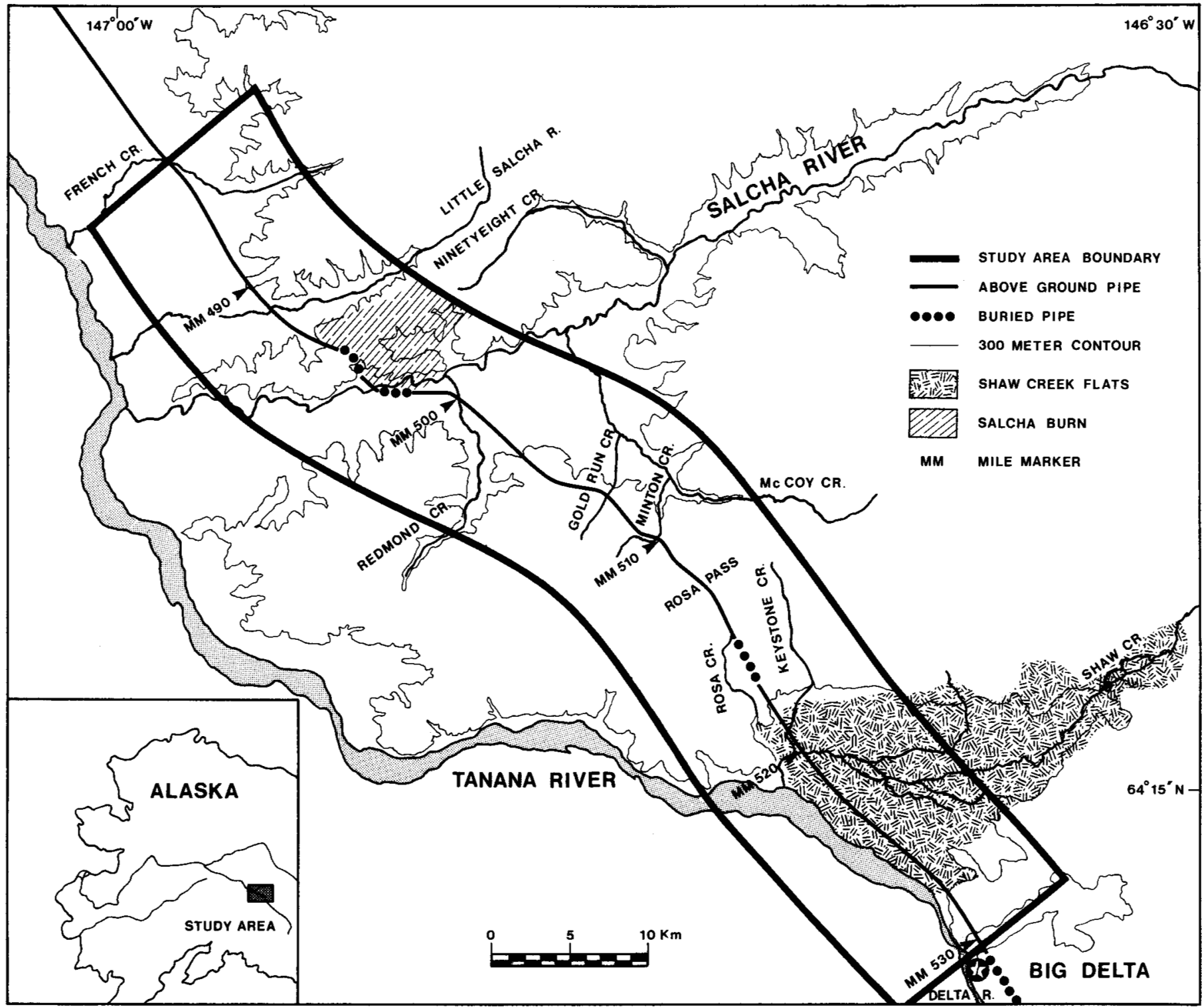

FIG. 1. The delta study area.

pipeline from a B-206 helicopter flying at an altitude of $50 \mathrm{~m}$ above the ground. Two farms are located near Shaw Creek, but activity at these locations usually occurs during the spring and summer. The pipeline follows a route approximately parallel to and $0.8-8.0 \mathrm{~km}$ away from the Richardson Highway.

\section{METHODS}

Distribution and number of moose were determined by aerial surveys, using a modified strip transect survey method (Eberhardt, 1981). Surveys were conducted on 23 February, 16 March and 31 March 1982 and on 15 February and 16 March 1983 using fixed-wing aircraft (Helio-courier and Cessna 206). Transect width was $600 \mathrm{~m}, 300 \mathrm{~m}$ on either side of the aircraft. Transects were spaced at $2 \mathrm{~km}$ intervals (30\% coverage) and were extended $7.5 \mathrm{~km}$ perpendicular to and on both sides of the pipeline.

Distances of moose from the pipeline were measured to the nearest $0.1 \mathrm{~km}$ on a topographic map and placed into a fre- quency distribution of five zones, each $65 \mathrm{~km}$ long and $1.5 \mathrm{~km}$ wide. To determine the relationship between numbers of moose and their distance from the pipeline, data were analyzed using a three-factor ANOVA (Zar, 1974:190).

During corridor surveys, the location and number of moose trails encountering the pipeline right-of-way were determined by snowmobile. In February 1982, $43 \mathrm{~km}$ of the pipeline were surveyed between miles 504 and 531; and in February-March $1983,67 \mathrm{~km}$ were surveyed between miles 489 and 531 . The pipeline route was traversed once during the 1982 survey and three times during the 1983 survey, the latter at intervals that allowed "old" and "fresh" trails to be distinguished.

The influence of the pipeline on movements of moose was analyzed by measuring the change in direction (configuration) of trails crossing the right-of-way. Each trail was divided into four segments: "from $20 \mathrm{~m}$ off right-of-way, to right-of-way edge" and "from right-of-way edge to center of pipeline" on both the approach and departure sides (Fig. 2). Trail configuration over two consecutive segments was derived by subtracting the bear- 


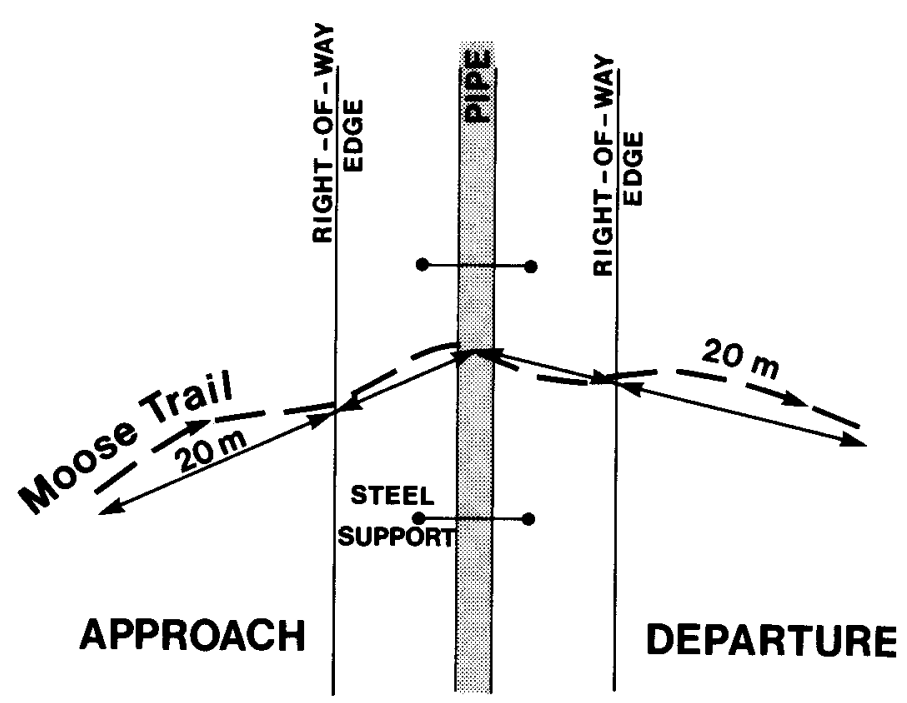

FIG. 2. Schematic of measurements taken at moose trails crossing the pipeline corridor.

ing of one station from the bearing of the next. The resulting value would fall between $0^{\circ}$ and $180^{\circ}$ (i.e., if the animal completely reversed directions, the value would be $180^{\circ}$ ). These difference values, measured for approach, crossing, and departure, were compared using paired t-tests. Using two-sample t-tests, these values were also compared to similar difference values measured on moose trails more than $200 \mathrm{~m}$ from the right-of-way in 1983 (see below).

Crossing success was defined as follows: (a) crossed without deflection, if the animal crossed the right-of-way within a lateral distance $<25 \mathrm{~m}$ from point of entry; (b) deflected then crossed, if the animal did not cross within $25 \mathrm{~m}$ of first entering the right-of-way, but did cross at another point; (c) deflected and did not cross, if the animal was deflected and then walked more than $20 \mathrm{~m}$ off the right-of-way without crossing the centerline of the right-of-way; (d) deflected, but whether crossing eventually occurred is unknown.

Clearances of the pipe from the ground were determined from "As-built" drawings and records provided by Alyeska Pipeline Service Company. These values included adjustments for pipe insulation and a measured correction factor (due to pad settling), resulting in an addition of $0.11 \mathrm{~m}$ to the "As-built" values.

During aerial surveys, vegetation type was recorded at 30 -second intervals (every $1.3 \mathrm{~km}$ ) for an area $50 \mathrm{~m}$ in diameter at the inside edge of the transect strip. Observations were summed to obtain a frequency distribution of vegetation types in the study area (Skoog, 1968; Marcum and Loftsgaarden, 1980). During corridor surveys, vegetation was recorded for a plot 50 $\mathrm{m} \times 50 \mathrm{~m}$ adjacent to the right-of-way edge on both sides of the pipeline and at $250 \mathrm{~m}$ intervals. For both aerial and corridor surveys, vegetation types were placed into one of the following categories: (1) conifer, (2) deciduous/mixedwood, (3) shrub, (4) wetlands (wet meadow, ponds and lakes), and (5) recently burned or disturbed.

In 1982 , a systematic subsample ( $20 \%$ ) of trails crossing the pipeline corridor was fore- and back-tracked for $200 \mathrm{~m}$ to provide a comparative record of moose trail configuration away from the pipeline corridor. Each trail was divided into four $50 \mathrm{~m}$ segments extending beyond each side of the right-of-way, and differences between compass bearings of these trail segments were averaged and used as a control to describe trail configura- tion. These values were compared to the mean of differences measured on the same trails within $20 \mathrm{~m}$ of the right-of-way (Fig. 2) using a paired t-test.

In 1983, control surveys were conducted to ensure that moose were not responding to the pipeline at greater distances than were previously measured. Moose trails located between $200 \mathrm{~m}$ and several $\mathrm{km}$ from the right-of-way were found by snowmobile. Each control trail was divided into four $20 \mathrm{~m}$ segments, and the bearing of each segment was recorded. The difference values were compared with those of trails that crossed the right-of-way and trails that were fore- and back-tracked within $200 \mathrm{~m}$ of the right-of-way using a one-factor ANOVA.

\section{RESULTS}

\section{Effects of the Pipeline on Moose Distribution}

To determine whether the presence of the pipeline and associated human activity affected moose distribution, the mean number of animals observed on transect was compared between five distance zones parallel to the pipeline (Fig. 3). There were no significant differences in the number of moose observed between any of the distance zones whether they were located on the east or west side of the pipeline $(F=0.356$, $\mathrm{df}=4,16$, $p>0.05$ ) or whether the observations were made in 1982 or 1983 $(\mathrm{F}=2.83, \mathrm{df}=4,16, \mathrm{p}>0.05)$. Habitat did not contribute significantly to the variation in moose density between zones, since the proportions of five habitat types in each zone were independent of distance from the pipeline both east $\left(x^{2}=16.5, \mathrm{df}\right.$ $=20,0.75>p>0.50)$ and west $\left(x^{2}=15.7, \mathrm{df}=12,0.25>\mathrm{p}>\right.$ 0.10 ) of the pipeline. Clearly, moose distribution was independent of distance from the pipeline, since moose were as likely to be observed in suitable habitats near the pipeline as they were farther away.

Moose showed similar habitat preferences whether they were adjacent to the pipeline or in areas up to $7.5 \mathrm{~km}$ away. Moose showed strong preferences for shrubs and burned or disturbed vegetation types and low preference for conifer and mixedwood habitats, both in the study area generally (aerial survey) and along the pipeline corridor (corridor surveys) (Table 1). High use of shrubs is related to the strong association of moose with riparian habitats and the 15-year-old Salcha Burn. Over 75\% of groups observed on aerial surveys and $75 \%$ of moose trails

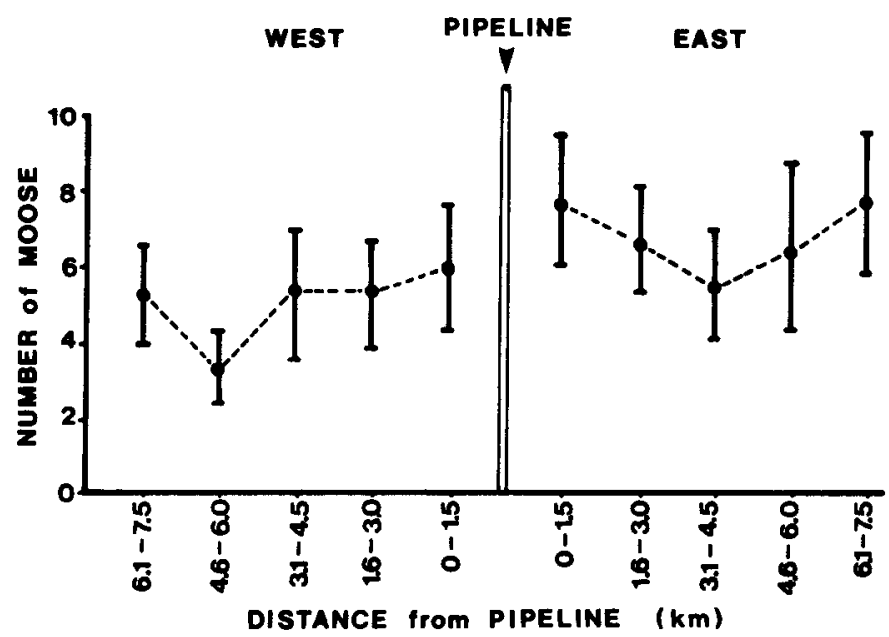

FIG. 3. Mean ( \pm S.E.) number of moose observed on transect within five distance zones east and west of the pipeline, 1982 and 1983 (all surveys combined). 
TABLE 1. Use of vegetation types by moose in relation to availability as determined by aerial and corridor surveys, 1982 and 1983

\begin{tabular}{|c|c|c|c|c|c|c|}
\hline \multirow[b]{3}{*}{ Vegetation type } & \multicolumn{3}{|c|}{ Aerial Surveys } & \multicolumn{3}{|c|}{ Corridor Surveys ${ }^{1}$} \\
\hline & \multicolumn{2}{|c|}{ Proportion } & \multirow[b]{2}{*}{$\begin{array}{l}\text { Signifi- } \\
\text { cance }^{3}\end{array}$} & \multicolumn{2}{|c|}{ Proportion } & \multirow[b]{2}{*}{$\begin{array}{l}\text { Signifi- } \\
\text { cance }^{3}\end{array}$} \\
\hline & $\begin{array}{c}\text { Available } \\
\mathrm{n}=612\end{array}$ & $\begin{array}{c}\text { Used }^{2} \\
\mathrm{n}=113\end{array}$ & & $\begin{array}{l}\text { Available } \\
\mathrm{n}=464\end{array}$ & $\begin{array}{c}\text { Used }^{2} \\
\mathrm{n}=302\end{array}$ & \\
\hline Conifer & 0.35 & $0.08 \pm 0.06$ & - & 0.52 & $0.33 \pm 0.06$ & - \\
\hline Deciduous/Mixedwood & 0.36 & $0.26 \pm 0.10$ & - & 0.17 & $0.14 \pm 0.05$ & NSD \\
\hline Shrub & 0.09 & $0.42 \pm 0.11$ & + & 0.24 & $0.44 \pm 0.07$ & + \\
\hline Wetlands & 0.14 & $0.03 \pm 0.04$ & - & 0.07 & $0.05 \pm 0.03$ & NSD \\
\hline Recently Burned/Disturbed & 0.06 & $0.22 \pm 0.09$ & + & 0.01 & $0.05 \pm 0.03$ & + \\
\hline
\end{tabular}

${ }^{1}$ Availability of vegetation types did not differ significantly between 1982 and 1983 surveys despite different sampling areas and were combined for the analysis $\left(\chi^{2}\right.$ $=6.8 \mathrm{df}=4, \mathrm{p}>0.05$ ).

${ }^{2} 90 \%$ family confidence interval on proportion used; technique follows Neu et al. (1974).

${ }^{3} \mathrm{NSD}=$ no significant difference.

$+=$ proportion greater than upper confidence limit, indicates use greater than expected $(p<0.10)$.

$-=$ proportion less than lower confidence limit, indicates use less than expected $(p<0.10)$.

observed along the pipeline were within $500 \mathrm{~m}$ of a stream. Use of disturbed vegetation occurred primarily within agricultural areas near Shaw Creek and along a power line right-of-way that parallels the pipeline between miles 514 and 530. Both aerial and corridor surveys indicated that wetland habitats were not important to moose during winter.

\section{Effects of Pipeline on Local Movements}

Results of corridor surveys indicate that most moose crossed the pipeline after entering the right-of-way, regardless of pipe mode. Of the trails encountering areas of above-ground pipe (n $=152$ ), $93.4 \%$ were known to cross the pipeline (Table 2 ). Only 10 of these trails did not cross the pipeline within $500 \mathrm{~m}$ of entering the right-of-way. Of these, one trail left the right-ofway after paralleling the pipe for $135 \mathrm{~m}$. The other 9 were not followed more than $500 \mathrm{~m}$ along the right-of-way, so their ultimate crossing success is unknown. Fifteen of the trails (8.6\%) that crossed the pipeline paralleled the pipe for more than $25 \mathrm{~m}$ from where they first entered the right-of-way before crossing. In 1983, the distance travelled parallel to the right-ofway before crossing was measured $(n=11)$. Mean $( \pm S$.E. $)$ length of parallel course was $96 \pm 18 \mathrm{~m}$, with a range of $34-117 \mathrm{~m}$.

In areas of buried pipe, all trails that encountered the right-ofway eventually crossed successfully (Table 2 ). In 1983, length of parallel course along the right-of-way was measured for buried pipe crossings $(n=23)$. Five trails $(21.7 \%)$ were deflected more than $25 \mathrm{~m}$ before crossing. Mean length of parallel course was $409 \pm 110 \mathrm{~m}$, with a range of $226-677 \mathrm{~m}$.

Moose exhibited meandering movements whether the animals crossed the pipeline or occupied areas distant from the pipeline. The mean change in direction for all segments of moose trails measured (1) at the crossing, (2) 50-200 m away, and (3) more than $200 \mathrm{~m}$ away from the pipeline varied between 32 and $36^{\circ}$ (Table 3 ). The mean change in direction at the point of crossing and $50-200 \mathrm{~m}$ from the pipeline did not differ significantly from the mean change in areas distant from the pipeline $(F=1.40$, df $=2,555, \mathrm{p}>0.05)$.

Moose did not change their pattern of movement as they traversed the pipeline corridor. The change in direction of travel when they entered the right-of-way was not significantly different from when they crossed the pipeline (paired $\mathrm{t}=0.007, \mathrm{df}=$ $114, p>0.05$ ) or left the right-of-way after crossing (paired $t=$ 0.149 , df $=114, p>0.05$ ). Similarly, the change in direction when they crossed the pipeline was not significantly different
TABLE 2. Crossing of pipeline by moose in relation to pipe mode and degree of lateral movement, 1982 and 1983 (numbers in parentheses are proportions of total)

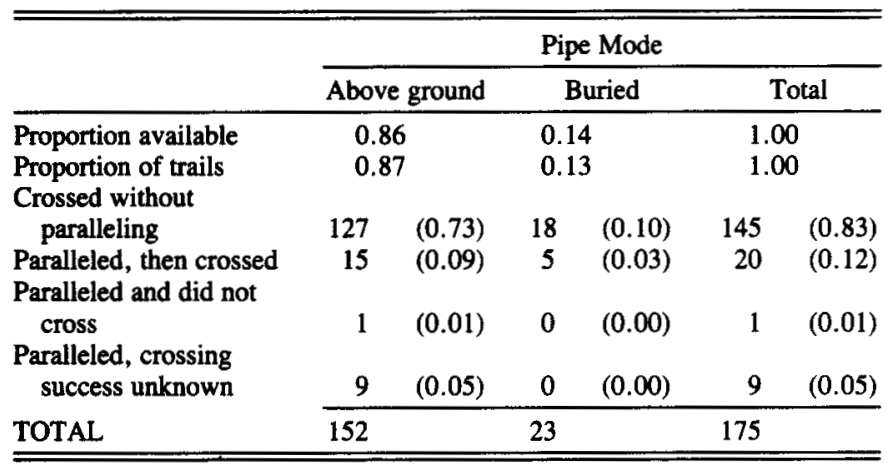

TABLE 3. Mean change in direction (degrees) for segments of moose trails (1) at the crossing, (2) 50-200 m away and (3) more than $200 \mathrm{~m}$ away from the pipeline, 1982 and 1983

\begin{tabular}{lcc}
\hline \hline $\begin{array}{l}\text { Distance from } \\
\text { pipeline }\end{array}$ & $\begin{array}{c}\text { Sample sizes: } \\
\text { trails/directional changes }\end{array}$ & $\begin{array}{c}\text { Change in direction } \\
\text { Mean } \pm \text { S.E. }\end{array}$ \\
\hline Right-of-way & $142 / 426$ & $32.6 \pm 1.4$ \\
$>50$ to $200 \mathrm{~m}$ & $12 / 31$ & $35.9 \pm 6.5$ \\
$>200 \mathrm{~m}$ & $29 / 86$ & $35.7 \pm 3.4$ \\
\hline \hline
\end{tabular}

from when they left the right-of-way (paired $t=0.113, \mathrm{df}=$ $114, p>0.05$ ).

Since moose may already be responding to the pipeline within $20 \mathrm{~m}$ of the right-of-way, the movements of moose as they approached the right-of-way $(50-200 \mathrm{~m})$ and as they crossed above-ground sections of pipe were examined. For each moose trail, the change in direction as they (1) approached the right-ofway (50-200 m) and (2) crossed the right-of-way was measured. Again, the mean difference in change of direction was not significantly different from zero (paired $\mathrm{t}=0.273$, df $=22$, $\mathrm{p}>0.05$ ).

Moose crossing the pipeline in the delta study area in February and March are probably resident animals wintering in the area. Most trails exhibited a meandering pattern of movement, and more than half $(54 \%)$ of the trails $(n=186)$ showed signs of feeding and bedding activity adjacent to the right-of-way. 
Proportions of east-bound and west-bound trails were nearly equal (51\% and $49 \%$ respectively).

\section{Factors Influencing Selection of Crossing Sites}

The selection of crossing sites by moose did not appear to be influenced by whether the pipe was buried or elevated above the ground. The number of trails found at buried and elevated sections of pipe did not differ significantly from the expected number, assuming that both pipe modes are equally available to moose $\left(x^{2}=0.11, \mathrm{df}=1, \mathrm{p}>0.05\right)$.

Along the elevated portions of the pipeline, the height of the pipe above ground had minimal influence on the selection of crossing sites by moose. A comparison of use versus availability of crossing sites over a range of pipe heights was conducted along a $16 \mathrm{~km}$ section of pipe (miles 510-520). This section of pipe was selected for analysis because it had the highest density of moose crossings in 1982 and 1983 and because the relatively short length of this section increased the likelihood that all pipe height categories were equally available to moose. Moose used pipe heights of under $1.5 \mathrm{~m}$ significantly less than expected and heights of 2.4-2.7 m significantly more than expected. All other categories were used in proportion to availability (Fig. 4).

Pipe heights at the initial encounter and subsequent crossing point were measured for 14 of the 15 moose trails that changed course upon entering the right-of-way. At the point of deflection, heights ranged from 1.4 to $2.9 \mathrm{~m}(\overline{\mathrm{x}}=2.1)$ and from 1.5 to $2.8 \mathrm{~m}(\overline{\mathrm{x}}=2.2)$ where they eventually crossed. There was no significant difference (paired $\mathrm{t}=0.485, \mathrm{df}=13$, $p>0.05, n=14$ ) between the height at first encountered and the eventual crossing site. One animal, which did not cross at all, first encountered the pipeline where the pipe height was $2.0 \mathrm{~m}$. Successful crossings (without deflection) by other moose were noted at all heights at which deflection occurred.

Special elevated sections of pipe ( $>3 \mathrm{~m}$ pipe-to-ground clearance) that were designed to facilitate movements of big game were not preferentially selected by moose as crossing sites. The 70 elevated sections were spaced at a mean $( \pm$ S.E. $)$ interval of $0.97 \pm 0.11 \mathrm{~km}$ and have a mean length of $30.5 \pm 2.7 \mathrm{~m}$ (range $18-128 \mathrm{~m}$ ). The length of all sections combined is $2.1 \mathrm{~km}$, or $3.2 \%$ of the pipeline route within the study area. The proportion of moose trails observed at these sites in 1982 and 1983 combined $(0.029, \mathrm{n}=175)$ was not significantly different than expected based on availability $\left(x^{2}=0.17, \mathrm{df}=1,0.75>\mathrm{p}>\right.$ $0.50)$.

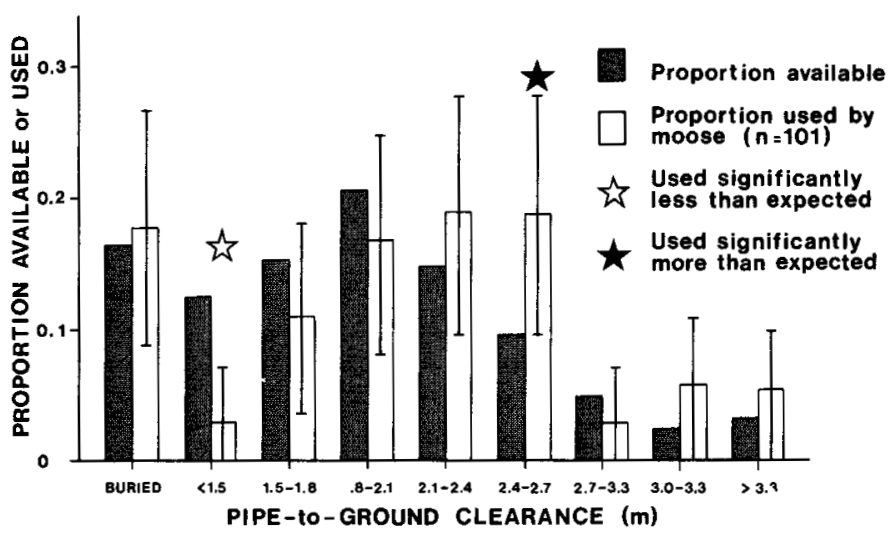

FIG. 4. Proportion ( $\pm 90 \%$ family confidence interval) of pipe-to-ground clearances used by moose in relation to proportion available, February-March 1982 and 1983 (miles 510-520). Technique follows Neu et al. (1974).
Habitat had a strong influence on where moose crossed the pipeline. Over $49 \%$ of moose trails were in shrub and burned/ disturbed habitat, compared to $25 \%$ availability (Table 1). Conifer, mixedwood and deciduous habitats, although accounting for $47 \%$ of crossing sites, were not preferentially used by moose. These forested habitats were often used if they were adjacent to riparian habitat, since $75 \%$ of trails were found within $500 \mathrm{~m}$ of a stream. These streams were lined with dense stands of willow (Salix spp.).

Snow depth along the pipeline did not appear to be a significant factor determining the location of moose crossings. Snowon-the-ground data for the Big Delta weather station indicated that values for snow depth were about $55 \%$ of normal in 1982 and $40 \%$ of normal in 1983 . When snow depths measured at moose trails as they entered the pipeline right-of-way were compared with those recorded systematically along the pipeline route, no significant differences $(p>0.05)$ were noted in either year (Table 4). Hence, moose appeared to select crossing areas with snow depths not different than expected based on availability.

TABLE 4. Comparison of mean ( \pm S.E.) snow depth (cm) measured systematically along the pipeline and at moose trails crossing the pipeline, 1982 and 1983

\begin{tabular}{cccc}
\hline \hline & & \multicolumn{2}{c}{ Snow depths } \\
& Moose trails & \\
1982 & Systematic & $43.3 \pm 1.5$ & T-value \\
\cline { 2 - 4 } $\mathbf{n}$ & $50.9 \pm 4.4$ & 79 & 1.94 \\
1983 & 15 & $46.6 \pm 1.8$ & \\
$\mathrm{n}$ & $44.5 \pm 2.4$ & 92 & -0.71 \\
\hline
\end{tabular}

${ }^{1}$ Measured at edge of right-of-way.

\section{DISCUSSION}

The results of this study support the hypothesis that the Trans-Alaska Pipeline has little or no effect on the adjacent distribution, habitat use and movement behaviour of moose. During late winter, moose distribution within $7.5 \mathrm{~km}$ was independent of the pipeline corridor, and habitat use within the study area generally and adjacent to the pipeline right-of-way was similar. Most moose crossed the pipeline without deflection, and movement patterns in the vicinity of the pipeline were not significantly different from movements in distant areas. Habitat preferences rather than pipe-to-ground clearance or pipe mode (buried versus elevated) appeared to be the most important factor affecting the selection of crossing sites by moose.

To date, effects on moose of disturbances associated with human activity and development facilities have been poorly documented. In general, moose appear to be more tolerant of disturbances than are other ungulates such as caribou and elk. For example, in northern Canada and Alaska moose react less strongly to low-level aircraft overflights than do caribou (Klein, 1973; McCourt and Horstman, 1974) and in Yellowstone National Park moose were more likely to remain close to heavily used hiking trails than were elk and mule deer (Chester, 1976).

When stimuli are constant and of low intensity, moose readily habituate to them. Tracy (1977) quantified responses of moose to human activity along McKinley Park Road in Alaska. Moose appeared to be very tolerant of disturbance, since $50 \%$ of moose 
observed within $200 \mathrm{~m}$ of the road showed no visible reaction to humans or vehicles.

The foregoing studies support our conclusion that moose behaviour is not significantly influenced by the pipeline corridor. Disturbances associated with the pipeline operation are constant and of low intensity and have been in place for about eight years at the time of this study. It is highly probable that moose have become habituated to existing disturbances.

Migratory patterns of moose in the study area are unclear, but it is doubtful that moose were migrating during the period covered by the present study. LeResche (1974) and Van Ballenberghe (1977) found that some moose migrate while others move only short distances between seasonal ranges. They also stated that if migrations do occur, movements to winter range and back to summer range usually take place in DecemberJanuary and March-April respectively. Gasaway et al. (1983) found that about $20 \%$ of the moose that calve on the Tanana Flats move onto wintering areas to the northeast of the study area, a migratory path that requires these animals to cross the pipeline corridor. We do not know whether most of the animals we observed along the pipeline spend the summer on the Tanana Flats or remain within the study area year round.

It is likely that the moose trails along and adjacent to the pipeline were made by resident animals. Once established on winter range, moose usually occupy a home range of less than $10 \mathrm{~km}^{2}$ (Houston, 1974; LeResche, 1974). Along the right-ofway, many trails consisted of multiple crossings. Since our aerial surveys showed that most moose were solitary in late winter, each multiple crossing may have represented a resident animal crossing the pipeline several times. The nearly equal number of east- and west-bound trails and the evidence of frequent browsing and bedding by moose adjacent to the rightof-way also support this conclusion.

Moose encountering the pipeline show a high rate of successful crossings, whether they are resident in the area or migrating between seasonal ranges. In the study area, $83 \%$ of observed moose trails crossed the pipeline within $25 \mathrm{~m}$ of entering the right-of-way and $94 \%$ crossed within $500 \mathrm{~m}$. These trails were considered to be made by moose resident on winter range. In the Nelchina Basin, Van Ballenberghe (1978) found that $84 \%$ of moose trails successfully crossed above-ground sections of the pipeline within $55 \mathrm{~m}$ of entering the right-of-way during two winters between 1975 and 1977. During the winter of 1977-78, Eide and Miller (1979), working in the same area, reported that a minimum of $96 \%$ of moose crossed the pipeline within $37 \mathrm{~m}$ of entering the right-of-way. Both Van Ballenberghe (1978) and Eide and Miller (1979) conducted their studies on migratory populations of moose and collected data throughout the winter, including periods of migration.

In the delta study area, habitat appeared to be the most important factor influencing the selection of crossing sites by moose rather than physical characteristics of the pipeline. Moose showed strong preference for shrub and disturbed habitats and a high proportion of trails occurred adjacent to streams. By contrast, buried and above-ground sections of pipe and most pipe-to-ground clearances were used in proportion to their occurrence. Pipe heights above $1.5 \mathrm{~m}$ were adequate for moose passage, but greater heights up to $2.7 \mathrm{~m}$ were preferred. Sections of pipe that were elevated greater than $3.0 \mathrm{~m}$ to facilitate ungulate movements were not preferentially used by moose, as was found for moose in the Nelchina Basin (Van Ballenberghe, 1978).
The selection of pipe heights by moose in the delta area appeared to be similar to that of moose in the Nelchina Basin. An analysis of use versus availability data from this study and from studies by Eide and Miller (1979) and Van Ballenberghe (1978) suggests that moose avoid the extremely low and high pipe heights and prefer heights within a range of $1.8-3.4 \mathrm{~m}$. However, caution should be used in the interpretation of these results since levels of "preference" varied according to the segment of pipeline under study and the height categories used in the analysis.

The effects of pipe heights of less than $1.5 \mathrm{~m}$ on moose movements are probably minor, because only $6.6 \%$ of pipe heights in the study area are in this category. In addition, since pipe heights of less than $1.5 \mathrm{~m}$ are widely scattered along the pipeline, moose have an opportunity to select alternative crossing sites.

An unbiased method to determine selection of pipe heights by moose is to examine trails that deflect at their initial encounter with the pipeline and subsequently cross at a different site. In our study, pipe heights at the point of deflection and at subsequent crossing sites were not significantly different. The same result was obtained by Van Ballenberghe (1978). These data suggest that factors other than pipe height may be influencing the selection of crossing sites by moose.

Travel between feeding (shrub) and bedding (conifer, deciduous/mixedwood) sites appeared to be the main motivation for resident moose to cross the right-of-way. Although daily activity patterns of moose during winter are poorly documented (Gasaway and Coady, 1974), studies of tame moose in Alaska showed that moose may spend an average of $64 \%$ of the daylight hours searching for and obtaining food (LeResche and Davis, 1971). Both Sigman (1977) and Linkswiler (1982) reported that moose had several cycles of feeding and bedding throughout the day. Sigman (1977) observed circular movements by moose (i.e., returning to one preferred bedding area after a feeding period), and both authors reported that moose move continually while feeding. If moose residing adjacent to the pipeline spend the majority of their time feeding, the meandering pattern of movement exhibited by many trails approaching and crossing the corridor is to be expected.

During this study, snow depths in the delta area were below normal. Van Ballenberghe (1978) expressed concern that unusually deep snows $(>80 \mathrm{~cm})$ would significantly reduce the size of pipeline " windows" available for moose crossing. Snow depths of $80 \mathrm{~cm}$ on the right-of-way would result in $54 \%$ of pipe heights in the delta study area being less than $1.5 \mathrm{~m}$ (from the bottom of the pipe to the top of the snow). If moose perceive these "pipe-to-snow" heights in the same way they perceive "pipe-to-ground" heights, then crossing success may be reduced and deflections may increase during periods of heavy snow cover in local areas.

In the Fairbanks area, maximum snow depths of over $80 \mathrm{~cm}$ (range $81-130 \mathrm{~cm}$ ) were recorded during 5 of 25 winters from 1959 to 1983 (Gasaway et al., 1983; NOAA, 1983). Snow characteristics are affected by local conditions, and it is difficult to predict moose behaviour along the pipeline during severe winters. In the delta area, winds are common in winter and can effectively reduce snow depths along the cleared right-of-way. For example, snow depths under the pipe were only $57 \%$ of those measured on the edge of the right-of-way in 1982 and an even lower $31 \%$ in 1983.

Since moose migrations generally occur after mid-March 
(LeResche, 1974), when snow depths are substantially lower, it is likely that resident moose would be most affected. The usual effect of high snow depths $(>80 \mathrm{~cm})$ on resident moose is a restriction in their movements (Coady, 1974). Although quantitative data are limited, home range sizes of moose have reportedly declined with increased snow depths. Knorre (1959) reported that home range size in Russia declined from about 225 ha (when snow depths were $62 \mathrm{~cm}$ ) to $97 \mathrm{ha}$ (when snow depths were 98 $\mathrm{cm}$ ); and Coady (1973) reported that home range size in Interior Alaska declined from $25 \mathrm{~km}^{2}$ (at $35 \mathrm{~cm}$ snow depth) to $1.3 \mathrm{~km}^{2}$ (at $65 \mathrm{~cm}$ ). Such dramatic declines in home range size suggest that daily movement would decrease and attempted crossings of the pipeline would also decrease under similar conditions. Under these conditions, any adverse effects on the movements of the moose population are more likely to occur as a consequence of the deep snow rather than as a result of the presence of the pipeline.

In conclusion, the distribution and local movements of resident moose during late winter did not appear to be significantly affected by the Trans-Alaska Pipeline. Heavy snows are not expected to seriously affect moose movements across the pipeline corridor. However, design of above-ground pipelines should take into consideration maximum snow depths in the area.

\section{ACKNOWLEDGEMENTS}

Funding and logistical support for this study were provided by Alyeska Pipeline Service Company. We wish to acknowledge the assistance and support of Mr. Ben Hilliker and Mr. Dennis Prendeville and the help and support of other Alyeska staff in Anchorage, Pump Stations 8, 9 and 10 and Glennallen.

We also thank the numerous personnel of Renewable Resources Consulting Services Ltd, who assisted with fieldwork: P. Bente, N. Cassara, C. Linkswiler, D. Masiak, J. Rose and J. Winters. R.D. Jakimchuk and D.R. Carruthers, of Renewable Resources Consulting Services Ltd., provided constructive reviews, and A. Cassidy aided in the data analysis. M. Tate typed several drafts of this manuscript.

\section{REFERENCES}

CHESTER, J.M. 1976. Human-wildlife interactions in the Gallatin Range, Yellowstone National Park, 1973-1974. M.S. Thesis, Montana State University, Bozeman, Montana. $114 \mathrm{p}$.

COADY, J.W. 1973. Moose research report. Juneau: Alaska Department of Fish and Game, Annual Report for Federal Aid in Wildlife Restoration Projects W-17-4 and W-17-5. $80 \mathrm{p}$.

1974. Influence of snow on behavior of moose. Naturaliste Canadien $101: 417-436$

EBERHARDT, L.L. 1981. Comments on transect methodology. In: Miller, F.L., and Gunn, A., eds. Symposium on Census and Inventory Methods for Populations and Habitats. Moscow, Idaho: Forest, Wildlife and Range Experiment Station, University of Idaho. 17-39.
EIDE, S., and MILLER, S. 1979. Effects of the Trans-Alaska pipeline on moose movements. Anchorage: Alaska Department of Fish and Game, Final Report for Federal Aid in Wildlife Restoration Project W-17-10. 27 p.

GASAWAY, W.C., and COADY, J.W. 1974. Review of energy requirements and rumen fermentation in moose and other ruminants. Naturaliste Canadien 191:227-262.

STEPHENSON, R.O,, DAVIS, J.L., SHEPHERD, P.E.K., and BURNS, O.E. 1983. Interrelationships of wolves, prey, and man in Interior Alaska. Wildlife Monographs 84. 50 p.

HOUSTON, D.B. 1974. Aspects of the social organization of moose. In: Geist, V., and Walther, F., eds. The Behavior of Ungulates and Its Relation to Management. Morges, Switzerland: IUCN Publications, New Series No. 24. 690-696.

KLEIN, D.R. 1972. Problems in conservation of mammals in the North. Biological Conservation 4(2):97-101.

1973. The reaction of some northern mammals to aircraft disturbance. International Congress of Game Biologists 11:377-383.

KNORRE, E.P. 1959. Ecology of the moose. Trudy Pechora-Ilych gos. Zapov. 7:5-167. (In Russian.)

LERESCHE, R.E. 1974. Moose migrations in North America. Naturaliste Canadien 101:393-415.

and DAVIS, J.L. 1971. Moose research report. Juneau: Alaska Department of Fish and Game, Annual Report for Federal Aid in Wildlife Restoration Project W-17-3. $156 \mathrm{p}$.

LINKSWILER, C. 1982. Factors influencing behavior and sightability of moose in Denali National Park, Alaska. M.S. Thesis, University of Alaska, Fairbanks. 84 p.

MARCUM, C.L., and LOFTSGAARDEN, D.O. 1980. A nonmapping technique for studying habitat preferences. Journal of Wildlife Management 44(4):963-968.

MCCOURT, K.H., and HORSTMAN, L.P. 1974. The reaction of barrenground caribou to aircraft. In: Jakimchuk, R.D., ed. The reaction of some mammals to aircraft and compressor station noise disturbance. Canadian Arctic Gas Ltd. Biological Report Series, Volume 23, Chapter 1. 36 p.

NATIONAL OCEANIC AND ATMOSPHERIC ADMINISTRATION. 19711983. Asheville, North Carolina: National Climatic Center. Vols. 57-69.

NEU, C.W., BYERS, C.R., and PEEK, J.M. 1974. A technique for analysis of utilization-availability data. Journal of Wildlife Management 38(3):541-545.

SIGMAN, M.J. 1977. The importance of the cow-calf bond to overwinter moose calf survival. M.S. Thesis, University of Alaska, Fairbanks. $185 \mathrm{p}$.

SKOOG, R.O. 1968. Ecology of the caribou (Rangifer tarandus granti) in Alaska. Ph.D. Thesis, University of California, Berkeley. 699 p.

TRACY, D.M. 1977. Reactions of wildlife to human activity along Mount McKinley National Park road. M.S. Thesis, University of Alaska, Fairbanks. $260 \mathrm{p}$.

UNITED STATES DEPARTMENT OF THE INTERIOR. 1972. Environmental setting of the proposed Trans-Alaska pipeline. Prepared by a special interagency task force for the federal task force on Alaska oil development. Final Environmental Impact Statement, Vol. 2. Washington, D.C.: U.S. Department of the Interior. $449 \mathrm{p}$.

VAN BALLENBERGHE, V. 1977. Migratory behavior of moose in southcentral Alaska. International Congress of Game Biologists 13:103-109.

1978. Final report on the effects of the Trans-Alaska pipeline on moose movements. Special Report No. 23. Anchorage, Alaska: Joint State/Federal Fish and Wildife Advisory Team. $40 \mathrm{p}$.

WEEDEN, R.B., and KLEIN, D.R. 1971. Wildlife and oil: a survey of critical issues in Alaska. The Polar Record 15(97):479-494.

ZAR, J.H. 1974. Biostatistical analysis. Englewood Cliffs, New Jersey: Prentice-Hall. 620 p. 